\title{
Combining Ability for Yield and its Components in Ethiopian Sorghum (Sorghum bicolor (L.) Moench) Landraces
}

\author{
Girma Mengistu1*, Amsalu Ayana ${ }^{2}$ and Ketema Belete ${ }^{3}$ \\ ${ }^{1}$ Bako Agricultural Research Center, P O Box 3, Bako, Ethiopia \\ ${ }^{2}$ Oromiya Agricultural Research Institute, P O Box 81265, Ethiopia \\ ${ }^{3}$ Haramaya University, Department of Plant Sciences, P O Box 38, Haramaya, Ethiopia
}

\begin{abstract}
Crossing sorghum [Sorghum bicolor (L.) Moench] obtained from different areas of Ethiopia were done in 2004/05 cropping season. In 2005/06 evaluation of $15 \mathrm{~F}_{1} \mathrm{~s}$ with their parents were done in a randomized complete block design with three replications at Bako. The study was conducted to estimate combining ability and determine type of gene actions involved in the inheritance of yield and yield components traits. Analysis of variance revealed that mean squares due to genotypes, parents and crosses were highly significant $(\mathrm{P}<0.01)$ for all the traits except for 100 kernel weight that were significant for crosses. Mean squares due to general combining ability (GCA) and specific combining ability (SCA) were highly significant for all characters studied, except non significant SCA for 100 kernel weight. For yield, three of the parents, 212646, 69543 and 69193 had the best general combiner and incorporating these parents for grain yield per panicle in sorghum breeding may be importatnt. Based on specific combining ability analysis for grain yield per panicle five hybrids $69543 \times 223506$, $212646 \times 223506$, 97MW5122 × 212646, 97MW5122 × 69543 and $212646 \times 69193$ were the best in the experiment. The estimate of variance components showed that the variance due to SCA was higher in magnitude than GCA in the case of days to maturity, panicle width, panicle weight, kernel number per panicle and grain yield. Therefore, these traits were predominantly under the control of non-additive type of gene actions. Whereas variance of GCA was higher than SCA in the case of days to flowering, plant height, leaf number per plant, leaf length, leaf width, leaf area, panicle length and 100 kernel weight indicating that additive type of gene action was playing a greater role in the inheritance of these traits.
\end{abstract}

Keywords: Combining Ability; Diallel; Gene Action; Sorghum bicolor

\section{Introduction}

Sorghum [Sorghum bicolor (L.) Moench] is the fifth leading cereal grain worldwide after wheat, rice, maize and barley with area coverage of about 42.7 million ha and total production of 56.96 million metric tons (FAO, 2004). Ethiopia is third largest sorghum producer in Africa next to Nigeria and Sudan (FAO, 2004). It is among the top four cereal crops next to tef, wheat and maize in Ethiopia (CSA, 2005). It ranks $3^{\text {rd }}$ in area cultivated to cereals and $2^{\text {nd }}$ in total production. The area under sorghum production was estimated to be 1.25 million ha with a total production and average yield of 1.72 million tons and 1.37 tons/ha, respectively (CSA, 2005).

Effective selection method for grain yield and other desirable traits requires information on the magnitude of useful genetic variances present in the parents, in terms of combining ability. Analysis of diallel data is usually conducted according to the methods of Griffing (1956) which partition the total variation of diallel data into general combining ability (GCA) of the parents and specific combining ability (SCA) of the crosses (Yan \& Hunt, 2002).

Combining ability helps to identify the better combiners which may be hybridized to exploit heterosis and select better crosses for further breeding (Singh and Chaudhary, 1985). Therefore, the objective of this study was to estimate GCA and SCA and determine the type of gene actions for yield and yield related traits of sorghum landraces.

\section{Materials and Methods}

Six sorghum landraces were crossed in a half diallel fashion at Bako Agricultural Research Center in 2004 main season. Bako is located at an altitude of 1650 masl. It lies between $9^{\circ} 6^{\prime} \mathrm{N}$ latitude and $37^{\circ} 09^{\prime} \mathrm{E}$ longitude in the sub-humid agro-ecology of the country. It annually receives $1242.1 \mathrm{~mm}$ rainfall.

The parents were from the zones (Kafa, Wello, Hararghe, Bale and Wellega) having distant cluster analysis and one advanced line from Melkasa Agricultural Research Center. Background information of these sorghum landraces is given in Table 1.

The entries were arranged in a randomized complete block design with three replications. A plot size of $3 \mathrm{~m}$ length was used with $1 \mathrm{~m}$ and $0.15 \mathrm{~m}$ spacing between rows and plants within the row, respectively. Fertilizers were applied at the rate of $46 / 46 \mathrm{~kg} \mathrm{ha}-1 \mathrm{~N} / \mathrm{P}_{2} \mathrm{O}_{5}$. Nitrogen was applied in split (half at planting and the other half at knee height). All other agronomic practices were carried out as needed. Data on days to flowering, days to maturity, plant height $(\mathrm{cm})$, number of leaf per plant, leaf length $(\mathrm{cm})$, leaf width $(\mathrm{cm})$, leaf area $\left(\mathrm{cm}^{2}\right)$, panicle length $(\mathrm{cm})$, panicle (head) width $(\mathrm{cm})$, head weight (g), kernel number per panicle, hundred-kernel weight $(\mathrm{g})$ and grain yield per panicle $(\mathrm{g})$ were recorded. Five plants were randomly taken from the plot and tagged for which the data were collected except for days to flowering and maturity recorded on plot basis. The grain yield was adjusted to $12 \%$ moisture. 
Table 1. Sorghum landraces and advanced lines used as parents for half diallel crossing.

\begin{tabular}{cllll}
\hline No. & Code & Collection Zone & Altitude & Grain color \\
\hline 1. & 97 MW5122 & Advanced line from MRC & - & Brown \\
2. & 69543 & Kafa & 1860 & White \\
3. & 212646 & Wello & 1690 & Dark red \\
4. & 223506 & Wellega & 1830 & Bright yellow \\
5. & 69046 & Bale & 1630 & Dark red \\
6. & 69193 & Hararghe & 1710 & Light yellow \\
\hline
\end{tabular}

${ }^{1} M R C=$ Melkasa Research Center; from Sr. No. 2-6 is code given by Institute of Biodiversity Conservation (IBC)

Analysis of variance was performed using SPAR-1, MSTAT-C (Fried, 1990) combining ability effect was done in AgroBase software programs (Agrobase, 2000), respectively. The data was analyzed according to Griffing's Model I, method 2 (Griffing, 1956).

The mathematical model for the combining ability (Griffing, 1956) is:

$X_{i j}=\mu+g_{i}+g_{j}+s_{i j}+\frac{1}{b c}\left(\sum_{k} \sum_{l} e_{i j k l}\right)$

where $S_{i j}=S_{j i} ; \mathrm{i}, \mathrm{j},=1, \ldots, \mathrm{p} ; \mathrm{k}=1, \ldots, \mathrm{b} ; \mathrm{l}=1$, $\ldots, \mathrm{c} ; \mathrm{X}_{\mathrm{ij}}$ is the mean of $\mathrm{i} \times \mathrm{j}^{\text {th }}$ genotype over $\mathrm{k}$ and $\mathrm{l} ; \mu=$ Population mean; $g_{i}=$ general combining ability of effect of $i^{\text {th }}$ parent; $g_{j}=$ general combining ability effect of $j^{\text {th }}$ parent; $s_{i j}=$ is the interaction, i.e., specific combining ability effect

$$
\frac{1}{b c} \sum_{k} \sum_{l} e_{i j k l} \text { Mean error }
$$

where $\mathrm{P}, \mathrm{b}$ and $\mathrm{c}=$ number of parents, block and sampled plants, respectively.

\section{Results and Discussion}

\subsection{Analysis of Variance}

The analysis of variance revealed highly significant $(\mathrm{P}<$ 0.01) difference among genotypes, parents and crosses for all traits (Table 2). Mean squares due to parents vs crosses were also highly significant for most of the traits considered including plant height, leaf length, leaf width, leaf area, panicle length, panicle width, panicle weight, kernel number per panicle, grain yield. The results showed that (Table 3) both GCA and SCA were significant, indicating the role of both additive and nonadditive gene action in the inheritance of these traits. However, mean squares due to SCA showed non significant for 100 kernel weight, indicating the major role of only additive gene actions in the inheritance of the character.

\subsection{Estimates of GCA Effects}

The estimated values of GCA effects are presented in (Table 4). The results showed negative and significant GCA effects for days to flowering in four parents including 69046, 97MW5122, 212646 and 69193 suggesting the contribution of these parents for earliness in crosses they were involved. Positive and significant
GCA effects were observed in 223506 and 69543 for the same trait. These parents greatly induced lateness in their crosses. The former parents were low general combiners (i.e. significant and negative GCA effects). The parent, 223506 greatly induced lateness in its crosses. The highest significant negative GCA effect (-15.03) was exhibited by 69046, whereas the highest positive GCA (18.31) was observed in 223506.

Four of the six parents had negative GCA effects, though only two of these (212646 and 69046) were found to be highly significant for days to maturity. Thus, the parents might have contributed for earliness of their crosses. The remaining two parents were found to have positive GCA effects, of which one was highly significant for the same trait. It appeared that these parents contributed for lateness of their crosses.

Five of the six parents were observed to have significant GCA effects for plant height, of which 3 had negative and two had positive effects. These parents with significant positive GCA effects were good combiners in increasing tallness, while those with significant negative GCA effects were good combiners in decreasing plant height. The parent, 212646 were average combiners for this trait (i.e. nonsignificant GCA effect). It was observed that there was a direct relationship between GCA effects of parents and mean plant height of parents and crosses. The tallest crosses involved at least one parent with high GCA effect and the relatively dwarf crosses involved at least one parent with low GCA effect.

Positive and significant GCA effects were exhibited by parents, 223506, 69543 and 97MW5122, for leaf length indicating good combiners for the trait, while the remaining parents showed negatively significant effects. The highest leaf length, $111.3 \mathrm{~cm}$ was exhibited by (97MW5122 x 223506) cross and it was also among the top exhibiting for the same trait. This situation appears to bring out the importance of additive gene actions. In the case of leaf width only two parents 223506 and 69543 exhibited positively significant GCA effects. The other three parents, 69046, 69193 and 97MW5122 were low general combiners having negatively significant for the trait. The parent, 212646 were average combiners for the same trait (i.e. nonsignificant GCA effect). 
Table 2. Mean squares due to genotypes, parents, crosses, $\mathrm{P}$ vs $\mathrm{C}$ and error for yield and other traits in $6 \mathrm{x} 6$ half diallel crosses of sorghum evaluated at Bako in 2005 cropping season.

\begin{tabular}{|c|c|c|c|c|c|c|}
\hline \multirow[t]{2}{*}{ Character } & \multicolumn{6}{|c|}{ Mean squares } \\
\hline & $\begin{array}{r}\text { Replication } \\
(\mathrm{df}=2)\end{array}$ & $\begin{array}{r}\text { Genotypes } \\
(\mathrm{df}=20)\end{array}$ & $\begin{array}{r}\text { Parents }(\mathrm{P}) \\
(\mathrm{df}=5)\end{array}$ & $\begin{array}{r}\text { Crosses }(\mathrm{C}) \\
(\mathrm{df}=14)\end{array}$ & $\begin{array}{c}\mathrm{P} \text { vs } \mathrm{C} \\
(\mathrm{df}=1)\end{array}$ & $\begin{array}{r}\text { Error } \\
(\mathrm{df}=40)\end{array}$ \\
\hline$\overline{\mathrm{DF}}$ & 104.83 & $1022.99^{* *}$ & $1370.59^{* *}$ & $970.80^{* *}$ & 15.56 & 20.49 \\
\hline $\mathrm{DM}$ & 42.49 & $787.96^{* *}$ & $977.43^{* *}$ & $775.97^{* *}$ & 8.46 & 46.26 \\
\hline $\mathrm{PH}$ & 6025.96 & $14838.29^{* *}$ & $14246.83^{* *}$ & $14438.61^{* *}$ & $23391.09^{* *}$ & 633.38 \\
\hline LNP & 8.84 & $13.49^{\text {** }}$ & $16.49^{* *}$ & $13.30^{* *}$ & 1.14 & 0.62 \\
\hline LL & 27.80 & $255.49^{* *}$ & $282.89^{* *}$ & $231.22^{* *}$ & $458.24^{* *}$ & 10.29 \\
\hline LW & 0.55 & $5.58^{* *}$ & $5.93^{* *}$ & $5.49^{* *}$ & $5.14^{* *}$ & 0.36 \\
\hline LA & 7146.83 & $70555.78^{* *}$ & $70841.21^{\text {** }}$ & $68412.39^{* *}$ & $99136.24^{* *}$ & 2884.20 \\
\hline PL & 4.86 & $183.11^{* *}$ & $293.86^{* *}$ & $144.10^{* *}$ & $175.49^{* *}$ & 6.09 \\
\hline PW & 0.33 & $14.29^{* *}$ & $10.72^{* *}$ & $14.26^{\text {** }}$ & $32.41^{\text {** }}$ & 1.15 \\
\hline PWT & 1820.35 & $10463.10^{* *}$ & $6772.13^{* *}$ & $10195.88^{* *}$ & $32669.28^{* *}$ & 567.87 \\
\hline KNPP & 1098830.43 & $14858145.20^{* *}$ & $6055971.89^{* *}$ & $17321072.58^{* *}$ & $24387141.51^{* *}$ & 1199296.50 \\
\hline HKW & 0.35 & $0.93^{* *}$ & $2.78^{* *}$ & $0.33^{*}$ & 0.02 & 0.15 \\
\hline GY & 3483.55 & $7393.67^{* *}$ & $2778.60^{* *}$ & $7755.52^{* *}$ & $25404.44^{* *}$ & 583.83 \\
\hline $\begin{array}{l}d f=\text { Degn } \\
\text { Plant heigh } \\
\text { Panicle leng } \\
\text { weight (g); }\end{array}$ & $\begin{array}{l}F^{*}=5 \% \text { sig } \\
=\text { Number } \\
=\text { Panicle } \\
\text { yield/panicle }\end{array}$ & $\begin{array}{l}\text { int level; }{ }^{* *}=1 \\
\text { ives per plant; L } \\
(\mathrm{cm}) ; P W T=\end{array}$ & $\begin{array}{l}\text { nificant level; D } \\
\text { Leaf length (cm) } \\
\text { le weight (g); K }\end{array}$ & $\begin{array}{l}\text { Days to flowering; } \\
=\text { Leaf width (cn } \\
=\text { Kernel number }\end{array}$ & $\begin{array}{l}M=\text { Days to mat } \\
L A=\text { Leaf area } \\
\text { panicle; } H K W=\end{array}$ & 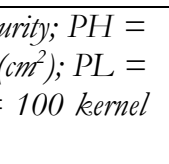 \\
\hline
\end{tabular}

Table 3. Mean squares due to general combining ability (GCA), specific combining ability (SCA) and error for yield and other traits in diallel crosses of sorghum.

\begin{tabular}{|c|c|c|c|}
\hline \multirow[t]{2}{*}{ Character } & \multicolumn{3}{|c|}{ Mean squares } \\
\hline & GCA $(\mathrm{df}=5)$ & SCA $(\mathrm{df}=15)$ & Error $(\mathrm{df}=40)$ \\
\hline Days to flowering & $1058.48^{* *}$ & $101.84^{* *}$ & 6.83 \\
\hline Days to maturity & $698.55^{* *}$ & $117.36^{* *}$ & 15.42 \\
\hline Plant height $(\mathrm{cm})$ & $15751.80^{* *}$ & $1344.20^{* *}$ & 211.13 \\
\hline Leaf number per plant & $13.34^{* *}$ & $1.55^{* *}$ & 0.21 \\
\hline Leaf length $(\mathrm{cm})$ & $247.50^{* *}$ & $31.05^{* *}$ & 3.43 \\
\hline Leaf width (cm) & $5.57^{* *}$ & $0.63^{* *}$ & 0.12 \\
\hline Leaf area $\left(\mathrm{cm}^{2}\right)$ & $70518.18^{* *}$ & $7852.07^{* *}$ & 961.40 \\
\hline Panicle length (cm) & $207.20^{* *}$ & $12.32^{* *}$ & 2.03 \\
\hline Panicle width (cm) & $10.91^{* *}$ & $2.72^{* *}$ & 0.38 \\
\hline Panicle weight $(\mathrm{g})$ & $6593.70^{* *}$ & $2452.37^{* *}$ & 189.29 \\
\hline Kernel number per panicle & $12298037.70^{* *}$ & $2470940.90^{* *}$ & 399765.49 \\
\hline 100 kernel weight $(\mathrm{g})$ & $1.04^{* *}$ & 0.04 & 0.05 \\
\hline Grain yield per panicle $(\mathrm{g})$ & $4102.10^{* *}$ & $1918.71^{* *}$ & 194.61 \\
\hline
\end{tabular}

${ }^{*}=5 \%$ significant level; ${ }^{* *}=1 \%$ significant level; $d f=$ degrees of freedom; GCA = General combining ability; SCA = Specific combining ability

Parents 223506 and 69543 had positive and significant GCA effects for leaf area, indicating they are good combiners for this trait. While two parents 69046 and 69193 showed negatively significant GCA for the trait. The remaining two parents were average combiners for this trait.

Parents 69543 and 97MW5122 were good combiners for panicle length having significant positive GCA effects, while the remaining four parents were poor combiners having negatively significant GCA effects. The cross (97MW5122 x 69543) with the highest mean performance for panicle length involved high $\mathrm{x}$ high indicating the importance of additive gene action. Parents 223506 and 69543 had positive and significant GCA effects for panicle width while there were negative and significant GCA effects for 69046 and 97MW5122. Similarly, the cross (69543 x 223506) having the highest panicle width involved parents high $\mathrm{x}$ high for the trait.

Only one parent, 69046, showed significant and negative GCA for panicle weight. From the remaining parents, 69193, 212646 and 69543 showed positively significant GCA. The parents, 223506 and 97MW5122 were average combiners.

Parents, 69543, 212646 and 97MW5122 had positive and significant GCA effects for kernel number per panicle and they were good combiners, while 69046 and 69193 were poor combiner since it had negative and significant GCA effects. 
For hundred kernel weight two parents, 69193 and 69046, showed positive and significant GCA effects. Three other parents, 69543, 212646 and 97MW5122 showed negatively significant GCA effects for the same trait. The parent 223506 was average combiner.

Table 4. Estimates of general combining ability (GCA) effects for grain yield and other agronomic traits of six parents of sorghum used in diallel cross.

\begin{tabular}{|c|c|c|c|c|c|c|c|c|}
\hline \multirow[t]{2}{*}{ Trait } & \multicolumn{6}{|c|}{ Parent } & \multicolumn{2}{|c|}{ SE } \\
\hline & 97MW5122 & 69543 & 212646 & 223506 & 69046 & 69193 & (gi) & (gi-gj) \\
\hline DF & $-4.90^{* *}$ & $7.64^{* *}$ & $-3.28^{* *}$ & $18.31^{* *}$ & $-15.03^{* *}$ & $-2.74^{* *}$ & 0.84 & 1.31 \\
\hline $\mathrm{DM}$ & -1.74 & $2.76^{*}$ & $-5.94^{* *}$ & $16.68^{* *}$ & $-10.53^{* *}$ & -1.24 & 1.27 & 1.96 \\
\hline $\mathrm{PH}$ & $-30.67^{* *}$ & $74.45^{* *}$ & -2.51 & $27.9^{* *}$ & $-44.22^{* *}$ & $-24.95^{* *}$ & 4.69 & 7.27 \\
\hline LNP & $-0.47^{* *}$ & $0.71^{* *}$ & $-0.61^{* *}$ & $2.31^{* *}$ & $-1.06^{* *}$ & $-0.88^{* *}$ & 0.15 & 0.23 \\
\hline LL & $3.54^{* *}$ & $4.27^{* *}$ & $-3.51^{* *}$ & $6.38^{* *}$ & $-7.98^{* *}$ & $-2.70^{* *}$ & 0.60 & 0.93 \\
\hline LW & $-0.31^{* *}$ & $0.51^{* *}$ & 0.14 & $1.23^{* *}$ & $-1.21^{* *}$ & $-0.37^{* *}$ & 0.11 & 0.17 \\
\hline LA & 3.46 & $64.48^{* *}$ & -19.83 & $136.03^{* *}$ & $-137.09^{* *}$ & $-47.04^{* *}$ & 10.01 & 15.50 \\
\hline PL & $4.49^{* *}$ & $8.02^{* *}$ & $-2.44^{* *}$ & $-1.62^{* *}$ & $-4.83^{* *}$ & $-3.62^{* *}$ & 0.46 & 0.71 \\
\hline PW & $-0.72^{* *}$ & $0.95^{* *}$ & -0.02 & $1.62^{* *}$ & $-1.65^{* *}$ & -0.18 & 0.20 & 0.31 \\
\hline PWT & 5.91 & $11.15^{*}$ & $15.16^{* *}$ & 5.21 & $-57.47^{* *}$ & $20.04^{* *}$ & 4.44 & 6.88 \\
\hline KNPP & $429.74^{*}$ & $1443.50^{* *}$ & $842.5^{* *}$ & -138.94 & $-2134.4^{* *}$ & $-442.44^{*}$ & 204.06 & 316.14 \\
\hline HKW & $-0.18^{*}$ & $-0.38^{* *}$ & $-0.29^{* *}$ & 0.01 & $0.25^{* *}$ & $0.57^{* *}$ & 0.07 & 0.11 \\
\hline GY & 7.63 & $12.39^{* *}$ & $14.68^{* *}$ & -1.21 & $-44.80^{* *}$ & $11.31^{*}$ & 4.50 & 6.98 \\
\hline
\end{tabular}

${ }^{*}=5 \%$ significant level; ${ }^{* *}=1 \%$ significant level; $D F=$ Days to flowering; $D M=$ Days to maturity; $P H=$ Plant height (cm); LNP = Number of leaves per plant; $L L=$ Leaf length $(\mathrm{cm}) ; L W=$ Leaf width $(\mathrm{cm}) ; L A=$ Leaf area $\left(\mathrm{cm}^{2}\right) ; P L=P$ anicle length $(\mathrm{cm}) ; P W=$ Panicle width (cm); PWT = Panicle weight (g); KNPP = Kernel number per panicle; HKW 100 kernel weight (g); GY = Grain yield/panicle (g)

For yield, the important trait, three of the parents, 212646, 69543 and 69193 exhibited positive and significant GCA effects. The parent, 69543 was observed to be high general combiner for the panicle characters. While the parent 97MW5122 showed positive and nonsignificant effects, indicating average combiner for the trait. The remaining two parents, 69046 and 223506 exhibited highly significant and nonsignificant negative effects, respectively, for the same trait. The highest mean performance for this trait was observed by the cross 69543 × 223506 with (high $\times$ low) indicating the importance of non-additive type of gene action. However, the lowest mean value was observed by the cross 223506 x 69046 involving the parents having low x low general combiners. Parent, 212646 was the best general combiner while 69046 was poorest one for grain yield per panicle. Therefore, in the future, the incorporation of parents 212646, 69543 and 69193 for grain yield per panicle in sorghum breeding programme may be worthwhile.

\subsection{Estimates of SCA Effects}

Estimates of SCA effects for the twelve traits that showed significant mean squares given in Table 5. Seven crosses showed positive SCA effects for days to flowering, of which four crosses exhibited significant effect. These latter crosses involved at least one parent with late flowering. The remaining 8 crosses had negative SCA effects, of which five had significant effects, indicating that these crosses had flowered earlier than what would be expected based on their parental performance. It was noted that most of these crosses involved at least one parent with low general combining ability effects. The highest positively significant SCA effect (22.88) was displayed by high $\mathrm{x}$ low combination (223506 x 690460). It seemed that 223506 having genes for lateness than 69046 as these two parents stand at opposite ends with respect to this trait.

Crosses such as 69543 x 223506, 69046 x 69193, 212646 × 223506, 212646 × 69046 and 97MW5122 x 69046 had a significant negative SCA effects for days to maturity followed by cross 212646 x 69193 having negative but non-significant SCA effects, indicating that these combinations of parents gave earliness in maturity. Other crosses including 223506 x 69046, 69543 x 69046 and 97MW5122 × 223506 had significant and positive SCA values. This showed combinations of these parents gave lateness in maturity. Two crosses 69046 x 69193 and 212646 × 69046 had significantly reduced plant height since they had significant negative SCA effects while the remaining crosses including 97MW5122 x 69193 and 212646 x 223506 had non significant SCA effects. However, four crosses 97MW5122 x 69543, $69543 \times$ 49046, 223506 x 69046, 97MW5122 x 212646 and 212646 x 69193 gave significant positive SCA effects for plant height. It can be concluded that combinations of these parents resulted in tall plant height. Except the last cross, the other crosses with significant positive SCA effects involved at least one of good combiner parent for the trait. While those with negative SCA effects having the combination of either both or one parents with low general combining ability.

Three crosses with significantly negative SCA effects for leaf length were 69046 × 69193, 69543 x 223506 and 97MW5122 x 69046, while seven crosses showed significant positive SCA for this trait. Most of the crosses 
For panicle length only one cross, 69543 x 69193 showed significant negative SCA effects, while crosses 97MW5122 x 69193, 69543 x 223506, 97MW5122 x 69046, 69543 x 212646 and 69046 × 69193 expressed significant positive SCA effects.

With respect to SCA effects for panicle weight only two cross, 223506 × 69193 and 212646 x 69046, exhibited negative and significant effect. Four crosses (212646 x 223506, 69543 x 223506, 97MW5122 x 212646 and 97MW5122 x 69543) showed positive and significant SCA effects for the trait. These crosses resulted from good combiner parents (i. e., high x high) indicating the importance of additive type of gene actions. These crosses displayed the higher mean performance for the trait.

Five of the 15 crosses showed negative SCA for kernel number per panicle, of which two crosses $223506 \mathrm{x}$ 69193 and 69543 x 69046 exhibited negative and significant effects. These crosses involved either average or poor combiner for the trait. On the other hand, five other crosses (69543 x 225606, 97MW5122 x 212646, $212646 \times 223506,97$ MW5122 x 69543 and $212646 \times$ 69193) showed positively significant SCA effects. The combination of these latter parents contributed for higher kernel number per panicle.

For grain yield per panicle five crosses (69543 x 223506 , 212646 x 223506, 97MW5122 x 212646, 97MW5122 x 69543 and $212646 \times$ 69193) exhibited positive and significant SCA, and these parental combinations enhanced grain yield per panicle. It was observed that significant and positive SCA effects were associated with crosses of high mean performance. Cross $223506 \mathrm{x}$ 69193 showed negatively significant SCA effect for this trait. From positively significant SCA effects and mean performances of the crosses, there would be possibility of obtaining hybrids which would perform better than the high yielding parent.

\subsection{Estimates of Variance Components}

The estimates of variance components due to general combining ability and specific combining ability are presented in Table 6. The ratio of GCA to SCA variances was greater than unity for days to flowering, plant height, leaf number per plant, node number per plant, leaf length, leaf width, leaf area, panicle length and 100 kernel weight indicating that additive type of gene action was playing a greater role in the inheritance of these traits. Similar findings were reported by authors for days to flowering (Rafiq et al., 2002). Moreover, Erenso (1998) reported similar result for plant height and 100 kernel weight; Amsalu (1987); Manickam and Vijendra Das (1994) for leaf number per plant. In contrast to the present study, higher magnitude of SCA variance were reported by several investigators (Manickam and Vijender Das, 1994; Umakanth et al., 2002) for days to flowering and plant height. Yang (1991) for number of leaves per plant and Pathak and Sanghi (1992); Manickam and Vijendra Das (1994) for leaf area indicated the predominance of non-additive gene actions for the traits.

However, the ratio of GCA to SCA variances was less than unity for days to maturity, panicle width, panicle weight, kernel number per panicle and grain yield. Therefore, these traits appeared predominantly under the control of non-additive type of gene actions. In line with this study (Umakanth, et al., 2000) for panicle weight; Erenso (1998) for kernel number per panicle; Hovny et al. (2000); Amsalu (1987); Umakanth et al. (2000) for grain yield. However, Toure et al. (1996) reported the importance of both additive as well as non-additive gene effects for grain yield.

Table 6. Estimates of variance components of general and specific combining ability of sorghum for yield and related traits.

\begin{tabular}{|c|c|c|c|}
\hline \multirow[b]{2}{*}{ Character } & \multicolumn{3}{|c|}{ Variance components } \\
\hline & GCA & SCA & GCA/SCA \\
\hline Days to flowering & 131.46 & 95.01 & 1.38 \\
\hline Days to maturity & 85.391 & 101.937 & 0.84 \\
\hline Plant height (cm) & 1942.58 & 1133.07 & 1.71 \\
\hline Leaf number per plant & 1.64 & 1.34 & 1.22 \\
\hline Nod number per plant & 1.98 & 1.86 & 1.06 \\
\hline Leaf length $(\mathrm{cm})$ & 30.51 & 27.62 & 1.10 \\
\hline Leaf width (cm) & 0.68 & 0.51 & 1.33 \\
\hline Leaf area $\left(\mathrm{cm}^{2}\right)$ & 8728.35 & 7160.67 & 1.22 \\
\hline Panicle length $(\mathrm{cm})$ & 25.646 & 10.288 & 2.49 \\
\hline Panicle width $(\mathrm{cm})$ & 1.316 & 2.335 & 0.56 \\
\hline Panicle weight (gm) & 800.55 & 2263.08 & 0.35 \\
\hline kernel number per panicle & 1499784.03 & 2071175.42 & 0.72 \\
\hline 100 kernel weight & 0.1243 & 0.016 & 7.77 \\
\hline Grain yield (g/panicle) & 488.436 & 1724.098 & 0.28 \\
\hline
\end{tabular}

$G C A=$ variance component for general combining ability, $S C A=$ variance component for specific combining ability 


\section{Conclusions}

The significant mean squares due to GCA for all characters and SCA for most of the traits indicated that contribution of additive and non-additive genes, respectively, to total genetic factor controlling the traits. Estimates of specific combining ability effects revealed that some combinations had effects that were significantly higher or lower than what have been predicted based on their parental performances. The variation is usually attributed to genetic factor of nonadditive components of gene action. Crosses with significant positive or negative SCA values for desirable traits indicated that hybridization is necessary to increase and decrease the traits.

\section{Acknowledgements}

We acknowledge the Oromiya Agriculture Research Institute for funding the project. It is also time to thank all the staff of Crop Breeding and Genetics Research Division of Bako Agricultural Research Center for the execution of the experiment.

\section{Reference}

Agrobase. 2000. Agrobase TM, 71 Waterloo St. winnipeg, Manitoba R3NNOS4, Canada.

Amsalu Ayana. 1987. Heterosis and Combining ability studies in grain sorghum (Sorghum bicolor (L.) Moench). M.Sc. Thesis, Mahatma Phule Agricultural University, India.

CSA (Central Statistical Authority). 2005. Agricultural Sample Survey Report on Area and Production for Major crops (Private Peasant Holdings Meher Season) for 2004/2005. The Federal Democratic Republic of Ethiopia. Statistical Bulletin, Addis Ababa, Ethiopia.

Erenso, D. 1998. Study of combining ability in lowland grain sorghum (Sorghum bicolor (L.) Moench). M.Sc. Thesis, Alemay University.

FAO (Food and Agriculture Organization). 2004. Production Year Book. Available: http: / / faostat.fao.org/faostat $/$ form.collection= production. Crops. Primary and Domain = Production $\&$ servlet $=1 \&$ has bulk $=0$ \&version $=$ ext \& language $=\mathrm{E}$. [Visited March 2, 2006).

Fried, R.D. 1990. MSTATC Software. Michigan State University, East Lansing, USA.

Griffing, B. 1956. Concept of general and specific combining ability in relation to diallel crossing systems. Journal of Biological Sciences 9: 463-493.

Hovny, M.R.A., El-Naggouly, O.O. and Hassaballa, E.A. 2000. Combining ability and heterosis in grain sorghum (Sorghum bicolor (L.) Moench). Jornal of Assiut of Agricultural Sciences 31(3): 1-16.

Manickam, S. and Vijendra Das, L.D. 1994. Line x tester analysis in forage sorghum. International Sorghum and Millet Newsletter 35: 79-80.

Pathak, H.C. and Sangh, A.K. 1992. Combining ability and heterosis studies forage sorghum (Sorghum bicolor (L.) Moench). Journal of Indian Genetics 50(1): 83-85.

Rafiq, S.M., Thete, R.Y., Madhusudhana, R. and Umakanth, A.U. 2002. Combining ability studies for grain yield and its components in postrainy season sorghum grown in medium-deep and shallow soils. International Sorghum Millets Newsletter 44: 33-37.

Singh, R.K. and Chaudhary, B.D. 1985. Biometrical Methods in Quantitative Genetic Analysis. Kalyani Publishers. New Delhi, India. pp.318.

Toure, A., Miller, F.R. and Rosenow, D.T. 1996. Heterosis and combining ability for grain yield and yield components in guinea sorghums. Jornal of African Crop Sciences (4): 383-391.

Umakanth, A.V., Madhusudhana, K., Madhavi Latha, P., Hema, K. and Kaul, S. 2002. Genetic architecture of yield and its contributing characters in postrainyseason sorghum. International Sorghum and Millets Newsletter 44: 37-40.

Yang, W.G. 1991. Studies on gene effect for main agronomic traits in Chinese sorghum. Journal of Scientica Agriculture Sinica 24(4): 26-31.

Yan, W. and Hunt, L. A. 2002. Biplot analysis of diallel data. Crop Scences 42(1): 21-30 